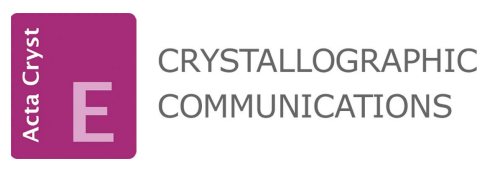

ISSN 2056-9890

Received 2 February 2018

Accepted 21 February 2018

Edited by A. Van der Lee, Université de Montpellier II, France

Keywords: NASICON structure; framework; crystal structure; BVS; CHARDI.

CCDC reference: 1824957

Supporting information: this article has supporting information at journals.iucr.org/e

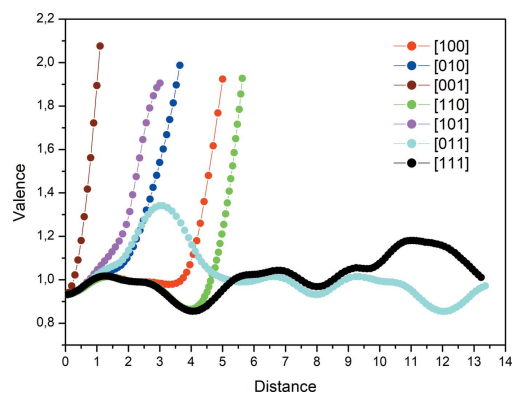

OPEN $\odot$ ACCESS

\section{Elaboration, structural study and validation of a new NASICON-type structure, $\mathrm{Na}_{0.72}\left(\mathrm{Cr}_{0.48}, \mathrm{Al}_{1.52}\right)\left(\mathrm{Mo}_{2.77}, \mathrm{Al}_{0.23}\right) \mathrm{O}_{12}$}

\author{
Manel Sonni, Imen Jendoubi and Mohamed Faouzi Zid*
}

University of Tunis El Manar, Faculty of Sciences of Tunis, Laboratory of Materials, Crystal Chemistry and Applied Thermodynamics, 2092 ElManar II, Tunis, Tunisia. *Correspondence e-mail: medfaouzi.zid57@gmail.com

The title compound, sodium chromium/aluminium molybdenum/aluminium dodecaoxide, $\mathrm{Na}_{0.72} \mathrm{Cr}_{0.48} \mathrm{Al}_{1.74} \mathrm{Mo}_{2.77} \mathrm{O}_{12}$, was prepared by solid-state reaction. Its crystal structure is related to NaSICON-type compounds. The framework is built up from $M 1 \mathrm{O}_{6}(M 1=\mathrm{Cr} / \mathrm{Al})$ octahedra and $M 2 \mathrm{O}_{4}(M 2=\mathrm{Mo} / \mathrm{Al})$ tetrahedra interconnected by corners. The three-dimensional framework contains cavities in which sodium cations are located. Two validation models (BVS and CHARDI) were used to confirm the proposed structural model. The mobility of $\mathrm{Na}^{+}$ions in the structure has been investigated by theoretical means.

\section{Chemical context}

The search for new and better solid electrolyte materials has grown considerably in recent years because of their amazing properties and their diverse applications in the field of solidstate chemistry. Indeed, many new molybdate phases with high ionic conductivity have been synthesized and structurally characterized by X-ray diffraction. A large number belong to the NASICON ('Na super ionic conductor') family, e.g. phosphate (Tkachev et al., 1984; Catti et al., 2004), arsenate (Harrison \& Phillips, 2001), sulfate (Slater \& Greaves, 1994) and molybdate (Sun et al., 2012; Kozhevnikova \& Imekhenova, 2006) based systems. The NASICON family groups together a set of phases of the same structural type with the general formula $A M_{2}\left(X \mathrm{O}_{4}\right)_{3}(A=$ alkali, $M=\mathrm{Ti}, \mathrm{Fe}, \mathrm{V}, \mathrm{Co}, \mathrm{Ni}$ and $X=\mathrm{P}$, As, Mo, W, S; Prabaharan et al., 2004). Apart from their superionic properties, a number of NASICON compounds have considerable potential for use in laser engineering, optics and electronics owing to their non-linear optical, electrical, magnetic and luminescent properties. It is in this context that we chose to explore $A-\mathrm{Cr}-\mathrm{Mo}-\mathrm{O}$ systems ( $A$ $=$ monovalent ion). A new phase $\mathrm{Na}_{0.72}\left(\mathrm{Cr}_{0.48}, \mathrm{Al}_{1.52}\right)$ $\left(\mathrm{Mo}_{2.77}, \mathrm{Al}_{0.23}\right) \mathrm{O}_{12}$ was synthesized by solid-state reaction. We present here its crystal structure and its validation by the CHARDI (charge distribution) and BVS (bond-valence-sum) methods.

\section{Structural commentary}

The structural unit of $\mathrm{Na}_{0.72}\left(\mathrm{Cr}_{0.48}, \mathrm{Al}_{1.52}\right)\left(\mathrm{Mo}_{2.77}, \mathrm{Al}_{0.23}\right) \mathrm{O}_{12}$ consists of one octahedron $M 1 \mathrm{O}_{6}(M 1=\mathrm{Cr} 1 / \mathrm{Al} 2)$ and one tetrahedron $M_{2} \mathrm{O}_{4}(M 2=\mathrm{Mo1} / \mathrm{Al} 1)$ that share corners. The charge compensation is provided by $\mathrm{Na}^{+}$cations (Fig. 1). The main construction unit in the anionic framework of the compound $\mathrm{Na}_{0.72}\left(\mathrm{Cr}_{0.48}, \mathrm{Al}_{1.52}\right)\left(\mathrm{Mo}_{2.77}, \mathrm{Al}_{0.23}\right) \mathrm{O}_{12}$ is formed by 
Table 1

Selected geometric parameters $\left(\AA,^{\circ}\right)$.

\begin{tabular}{|c|c|c|c|}
\hline $\mathrm{Mo} 1-\mathrm{O} 2^{\mathrm{i}}$ & $1.7358(15)$ & $\mathrm{Cr} 1-\mathrm{O} 2^{\mathrm{v}}$ & $1.9721(16)$ \\
\hline $\mathrm{Mo1}-\mathrm{O} 2$ & $1.7359(15)$ & $\mathrm{Cr} 1-\mathrm{O} 2^{\mathrm{vi}}$ & $1.9721(16)$ \\
\hline Mo1-O1 & $1.7540(16)$ & $\mathrm{Na} 1-\mathrm{O} 1^{\mathrm{ii}}$ & $2.4987(15)$ \\
\hline $\mathrm{Mo} 1-\mathrm{O}^{\mathrm{i}}$ & $1.7540(15)$ & $\mathrm{Na} 1-\mathrm{O} 1^{\mathrm{vii}}$ & $2.4987(15)$ \\
\hline $\mathrm{Cr} 1-\mathrm{O} 1^{\mathrm{ii}}$ & $1.9668(16)$ & $\mathrm{Na} 1-\mathrm{O}_{1}^{\mathrm{iii}}$ & $2.4987(15)$ \\
\hline $\mathrm{Cr} 1-\mathrm{O} 1^{\mathrm{iii}}$ & $1.9668(16)$ & $\mathrm{Na} 1-\mathrm{O} 1^{\text {viii }}$ & $2.4987(15)$ \\
\hline $\mathrm{Cr} 1-\mathrm{O} 1^{\mathrm{iv}}$ & $1.9669(16)$ & $\mathrm{Na} 1-\mathrm{O} 1^{\mathrm{iv}}$ & $2.4987(15)$ \\
\hline $\mathrm{Cr} 1-\mathrm{O} 2$ & $1.9720(16)$ & $\mathrm{Na} 1-\mathrm{O} 1^{\mathrm{ix}}$ & $2.4987(15)$ \\
\hline $\mathrm{O} 2^{\mathrm{i}}-\mathrm{Mo} 1-\mathrm{O} 2$ & $109.56(11)$ & $\mathrm{O} 1^{\mathrm{iv}}-\mathrm{Cr} 1-\mathrm{O} 2^{\mathrm{vi}}$ & $88.68(7)$ \\
\hline $\mathrm{O} 2^{\mathrm{i}}-\mathrm{Mo} 1-\mathrm{O} 1$ & $107.85(8)$ & $\mathrm{O} 2-\mathrm{Cr} 1-\mathrm{O} 2^{\mathrm{vi}}$ & $91.35(7)$ \\
\hline $\mathrm{O} 2-\mathrm{Mo1}-\mathrm{O} 1$ & $111.40(8)$ & $\mathrm{O} 2^{\mathrm{v}}-\mathrm{Cr} 1-\mathrm{O} 2^{\mathrm{vi}}$ & 91.35 (7) \\
\hline $\mathrm{O} 2^{\mathrm{i}}-\mathrm{Mo} 1-\mathrm{O} 1^{\mathrm{i}}$ & $111.40(8)$ & $\mathrm{O} 1^{\mathrm{ii}}-\mathrm{Na} 1-\mathrm{O} 1^{\mathrm{vii}}$ & 180.0 \\
\hline $\mathrm{O} 2-\mathrm{Mo} 1-\mathrm{O} 1^{\mathrm{i}}$ & $107.86(8)$ & $\mathrm{O} 1^{\mathrm{ii}}-\mathrm{Na} 1-\mathrm{O} 1^{\mathrm{iii}}$ & $65.74(6)$ \\
\hline $\mathrm{O} 1-\mathrm{Mo} 1-\mathrm{O} 1^{\mathrm{i}}$ & $108.80(11)$ & $\mathrm{O} 1^{\mathrm{vii}}-\mathrm{Na} 1-\mathrm{O} 1^{\mathrm{iii}}$ & $114.26(6)$ \\
\hline $\mathrm{O} 1^{\mathrm{ii}}-\mathrm{Cr} 1-\mathrm{O} 1^{\mathrm{iii}}$ & $87.18(7)$ & $\mathrm{O} 1^{\mathrm{ii}}-\mathrm{Na} 1-\mathrm{O} 1^{\mathrm{viii}}$ & $114.26(6)$ \\
\hline $\mathrm{O} 1^{\mathrm{ii}}-\mathrm{Cr} 1-\mathrm{O} 1^{\mathrm{iv}}$ & $87.18(7)$ & $\mathrm{O} 1^{\mathrm{vii}}-\mathrm{Na} 1-\mathrm{O} 1^{\mathrm{viii}}$ & $65.74(6)$ \\
\hline $\mathrm{O} 1^{\mathrm{iii}}-\mathrm{Cr} 1-\mathrm{O} 1^{\mathrm{iv}}$ & $87.18(7)$ & $\mathrm{O} 1^{\mathrm{iii}}-\mathrm{Na} 1-\mathrm{O} 1^{\mathrm{viii}}$ & 180.0 \\
\hline $\mathrm{O} 1^{\mathrm{ii}}-\mathrm{Cr} 1-\mathrm{O} 2$ & $92.79(7)$ & $\mathrm{O} 1^{\mathrm{ii}}-\mathrm{Na} 1-\mathrm{O} 1^{\mathrm{iv}}$ & $65.74(6)$ \\
\hline $\mathrm{O} 1^{\mathrm{iii}}-\mathrm{Cr} 1-\mathrm{O} 2$ & $88.68(7)$ & $\mathrm{O} 1^{\mathrm{vii}}-\mathrm{Na} 1-\mathrm{O} 1^{\mathrm{iv}}$ & $114.26(6)$ \\
\hline $\mathrm{O} 1^{\mathrm{iv}}-\mathrm{Cr} 1-\mathrm{O} 2$ & $175.86(7)$ & $\mathrm{O} 1^{\mathrm{iii}}-\mathrm{Na} 1-\mathrm{O} 1^{\mathrm{iv}}$ & $65.74(6)$ \\
\hline $\mathrm{O} 1^{\mathrm{ii}}-\mathrm{Cr} 1-\mathrm{O} 2^{\mathrm{v}}$ & $88.68(7)$ & $\mathrm{O} 1^{\mathrm{viii}}-\mathrm{Na} 1-\mathrm{O} 1^{\mathrm{iv}}$ & $114.26(6)$ \\
\hline $\mathrm{O} 1^{\mathrm{iii}}-\mathrm{Cr} 1-\mathrm{O} 2^{\mathrm{v}}$ & $175.86(7)$ & $\mathrm{O} 1^{\mathrm{ii}}-\mathrm{Na} 1-\mathrm{O} 1^{\mathrm{ix}}$ & $114.26(6)$ \\
\hline $\mathrm{O} 1^{\mathrm{iv}}-\mathrm{Cr} 1-\mathrm{O} 2^{\mathrm{v}}$ & $92.79(7)$ & $\mathrm{O} 1^{\mathrm{vii}}-\mathrm{Na} 1-\mathrm{O} 1^{\mathrm{ix}}$ & $65.74(6)$ \\
\hline $\mathrm{O} 2-\mathrm{Cr} 1-\mathrm{O} 2^{\mathrm{v}}$ & $91.35(7)$ & $\mathrm{O} 1^{\mathrm{iii}}-\mathrm{Na} 1-\mathrm{O} 1^{\mathrm{ix}}$ & $114.26(6)$ \\
\hline $\mathrm{O} 1^{\mathrm{ii}}-\mathrm{Cr} 1-\mathrm{O} 2^{\mathrm{vi}}$ & $175.85(7)$ & $\mathrm{O} 1^{\mathrm{viii}}-\mathrm{Na} 1-\mathrm{O} 1^{\mathrm{ix}}$ & $65.74(6)$ \\
\hline $\mathrm{O} 1^{\mathrm{iii}}-\mathrm{Cr} 1-\mathrm{O} 2^{\mathrm{vi}}$ & $92.79(7)$ & $\mathrm{O} 1^{\mathrm{iv}}-\mathrm{Na} 1-\mathrm{O} 1^{\mathrm{ix}}$ & 180.0 \\
\hline
\end{tabular}

Symmetry codes: (i) $\quad x-y,-y,-z+\frac{3}{2} ; \quad$ (ii) $\quad x-y-\frac{1}{3}, x-\frac{2}{3},-z+\frac{4}{3}$; $\quad$ (iii) $-x+\frac{2}{3},-y+\frac{1}{3},-z+\frac{4}{3} ; \quad$ (iv) $y-\frac{1}{3},-x+y+\frac{1}{3},-z+\frac{4}{3} ; \quad$ (v) $-x+y,-x, z$; (vi) $-y, x-y, z ; \quad$ (vii) $\quad-x+y+\frac{1}{3},-x+\frac{2}{3}, z-\frac{1}{3} ; \quad$ (viii) $\quad x-\frac{2}{3}, y-\frac{1}{3}, z-\frac{1}{3} ; \quad$ (ix) $-y+\frac{1}{3}, x-y-\frac{1}{3}, z-\frac{1}{3}$.

two $M 1 \mathrm{O}_{6}$ octahedra interconnected by three $M 2 \mathrm{O}_{4}$ tetrahedra located along the $c$ axis. Geometrical parameters are given in Table 1 . This assembly forms $M 1_{2} M 2_{3} \mathrm{O}_{18}$ units (Fig. 2). The junction between these units, provided by the formation of mixed bridges of the $M 1-\mathrm{O}-M 2$ type, leads to a

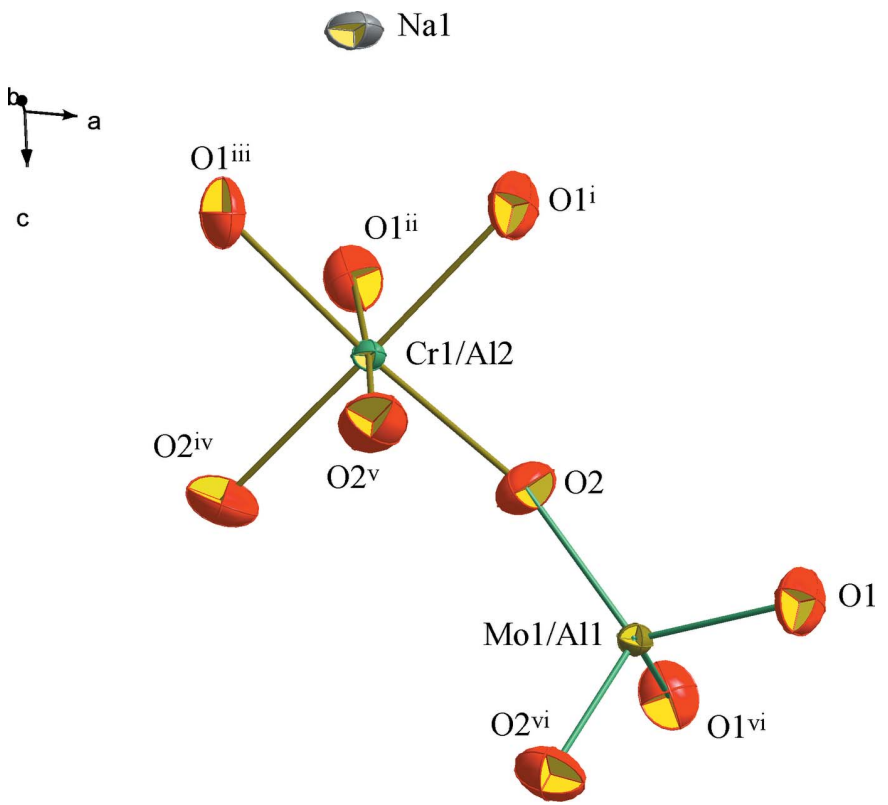

Figure 1

Structural unit of $\mathrm{Na}_{0.72}\left(\mathrm{Cr}_{0.48}, \mathrm{Al}_{1.52}\right)\left(\mathrm{Mo}_{2.77}, \mathrm{Al}_{0.23}\right) \mathrm{O}_{12}$. Displacement ellipsoids are drawn at the $50 \%$ probability level. [Symmetry codes: (i) $\frac{2}{3}-x, \frac{1}{3}-y, \frac{1}{3}-z$; (ii) $-\frac{1}{3}+x-y,-\frac{2}{3}+x, \frac{1}{3}-z$; (iii) $-\frac{1}{3}+y, \frac{1}{3}-x+y, \frac{4}{3}-z$; (iv) $-x+y,-x, z$; (v) $-x, x-z, z$; (vi) $x-y,-y, \frac{3}{2}-z$.]

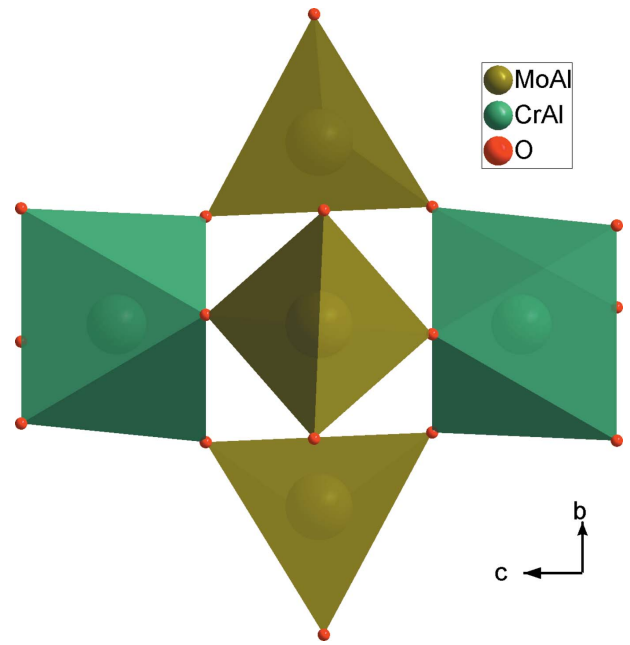

Figure 2

Projection of an $M 1_{2} M 2_{3} \mathrm{O}_{18}$ unit along the $a$ axis.

three-dimensional framework with cavities parallel to the [100] and [010] directions in which the $\mathrm{Na}^{+}$cations are located (Fig. 3). Indeed, each $M 1 \mathrm{O}_{6}$ octahedron share its six corners with different $M 2 \mathrm{O}_{4}$ tetrahedra, leading to $M 1 M 2_{6} \mathrm{O}_{24}$ clusters (Fig. 4). The two validation models BVS (Brown \& Altermatt, 1985; Brown, 2002; Adams, 2003) and CHARDI (Hoppe et al., 1989; Nespolo et al., 2001; Nespolo, 2001) confirm the

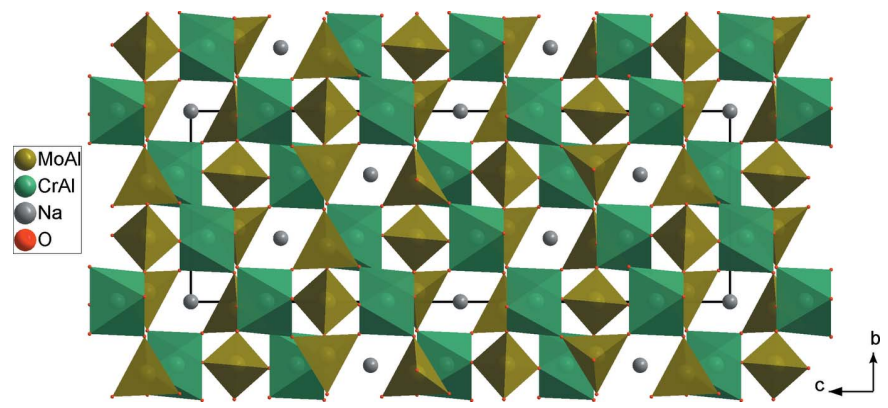

Figure 3

Projection of $\mathrm{Na}_{0.72}\left(\mathrm{Cr}_{0.48}, \mathrm{Al}_{1.52}\right)\left(\mathrm{Mo}_{2.77}, \mathrm{Al}_{0.23}\right) \mathrm{O}_{12}$ along the $a$ axis.

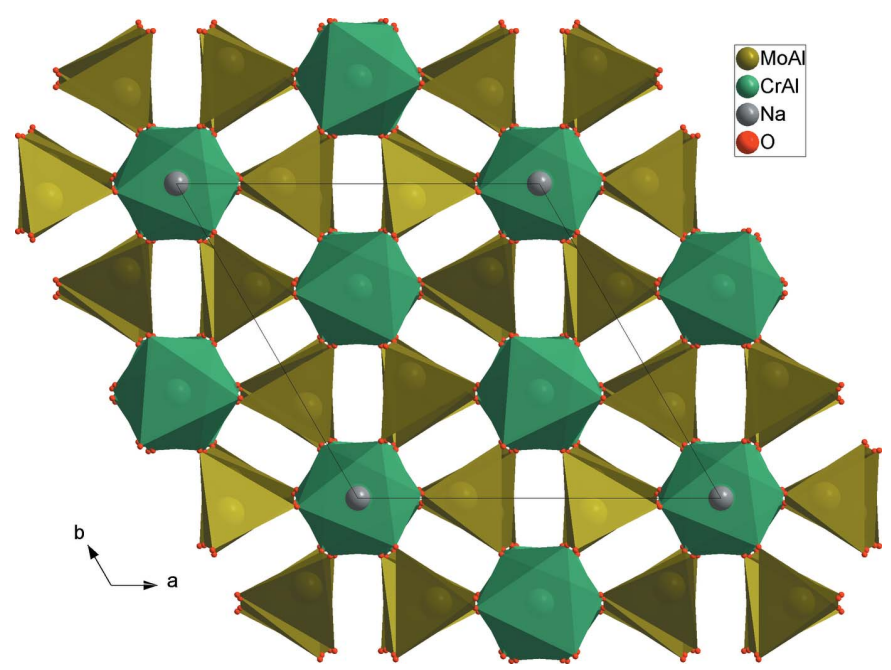

Figure 4

Projection of $\mathrm{Na}_{0.72}\left(\mathrm{Cr}_{0.48}, \mathrm{Al}_{1.52}\right)\left(\mathrm{Mo}_{2.77}, \mathrm{Al}_{0.23}\right) \mathrm{O}_{12}$ along the $c$ axis. 
Table 2

CHARDI and BVS analyses for the cations in the $\mathrm{Na}_{0.72} \mathrm{Cr}_{0.48} \mathrm{Al}_{1.76} \mathrm{Mo}_{2.77} \mathrm{O}_{12}$ compound.

$q(i)=$ formal oxidation number; $\operatorname{sof}(i)=$ site occupancy; $\mathrm{CN}(i)=$ classical coordination number; $Q(i)=$ calculated charge; $V(i)=$ calculated valence; ECoN $(i)=$ coordination number; $d_{\text {mean }}(i)=$ mean distance; $d_{\text {med }}(i)=$ median distance.

\begin{tabular}{lllllll}
\hline Cation & $q(i) \cdot \operatorname{sof}(i)$ & $Q(i)$ & $V(i)$ & $\mathrm{CN}(i)$ & $\mathrm{ECoN}(i)$ & $d_{\text {mean }}$ \\
\hline Mo1/Al1 & 5.78 & 5.77 & 5.8426 & 4 & 4.00 & 1.7448 \\
M(Cr1/A12) & 3.000 & 2.99 & 2.9397 & 6 & 6.00 & 1.7443 \\
Na1 & 0.72 & 0.71 & 0.6893 & 6 & 6.00 & 1.9696 \\
\hline
\end{tabular}

$\sigma_{\text {cat }}$ is the dispersion factor for cationic charges where $\sigma_{\text {cat }}=\left[\Sigma_{i}\left(q_{i}-Q_{i}\right)^{2} / N-1\right]^{1 / 2}=0.025$.

proposed structural model, in particular the distribution at mixed sites. The calculated load values $Q(i)$ and valences $V(i)$ are in good agreement with the oxidation degrees weighted by the occupancy rates. The dispersion factor $\sigma_{\text {cat }}$, which measures the deviation of the calculated cationic charges, is equal to $0.3 \%$ (Table 2). The variation of the bond-valence sum of sodium as a function of the distance travelled in different directions shows that the [011] and [111] directions are the most favorable directions for the mobility of sodium. The paths along these directions have the same shape when the distance travelled is about $13.5 \AA$ and the maximum valence is about 1.4 valence units (Fig. 5). The representation of the Na migration path in the direction [011] is shown in Fig. 6 .

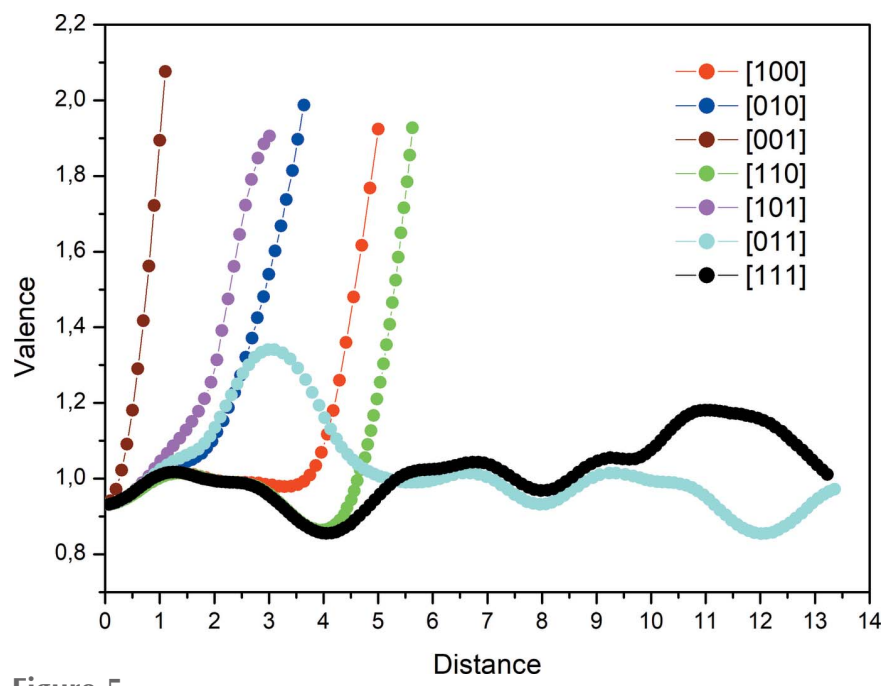

Figure 5

Ionic pathway valence curves of the title compound.

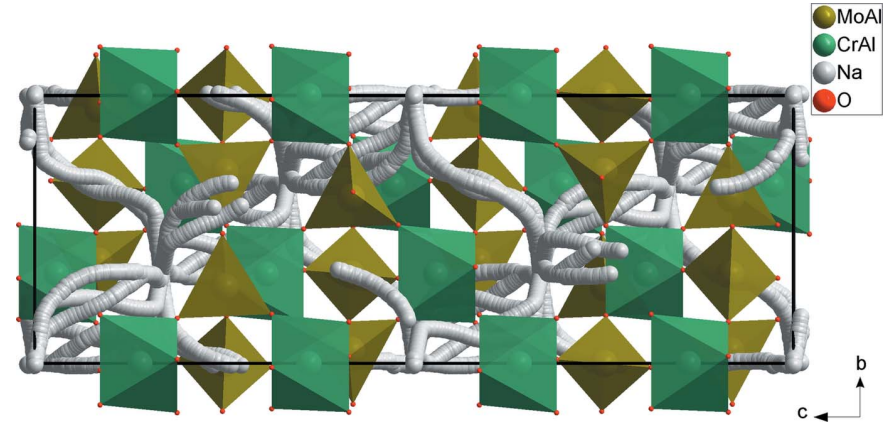

Figure 6

Modelling of the $\mathrm{Na}^{+}$pathway in $\mathrm{Na}_{0.72}\left(\mathrm{Cr}_{0.48}, \mathrm{Al}_{1.52}\right)\left(\mathrm{Mo}_{2.77}, \mathrm{Al}_{0.23}\right) \mathrm{O}_{12}$.

\section{Database survey}

A comparison between the structures of the title compound and those of other NASICON-type compounds reveals that other compounds also crystallize in the $R \overline{3} c$ space group with similar unit-cell parameters. When compared to $\mathrm{NaZr}_{2}\left(\mathrm{AsO}_{4}\right)_{3}$ (Coquerel et al., 1983) and $\mathrm{Na}_{4} \mathrm{Co}_{3} \mathrm{Mo}_{22.33} \mathrm{O}_{72}$ (Chakir et al., 2003), the only difference observed is the occupancy of the sites $6 b, 12 c$ and $18 e$. In $\mathrm{NaZr}_{2}\left(\mathrm{AsO}_{4}\right)_{3}$, the sites are fully occupied, whereas in $\mathrm{Na}_{4} \mathrm{Co}_{3} \mathrm{Mo}_{22.33} \mathrm{O}_{72}$, the $6 b$ site is not totally occupied, and the $12 c$ site is occupied by both Co and Mo. In the title compound, the $6 b$ site is partially occupied and the $12 c$ and $18 e$ sites are mixed $\mathrm{Cr} / \mathrm{Al}$ and $\mathrm{Mo} / \mathrm{Al}$ sites, respectively.

\section{Synthesis and crystallization}

During the investigation of the $A-\mathrm{Mo}-\mathrm{Cr}-\mathrm{O}$ phase diagrams $(A=\mathrm{Li}, \mathrm{Na}, \mathrm{Ag})$, the new compound $\mathrm{Na}_{0.72}\left(\mathrm{Cr}_{0.48}, \mathrm{Al}_{1.52}\right)$ $\left(\mathrm{Mo}_{2.77}, \mathrm{Al}_{0.23}\right)_{12}$ was established. The crystals were obtained by grinding in an agate mortar the reagents $\mathrm{NaNO}_{3}$, $\mathrm{Cr}\left(\mathrm{NO}_{3}\right)_{3} \cdot 9 \mathrm{H}_{2} \mathrm{O}$ and $\left(\mathrm{NH}_{4}\right)_{6} \mathrm{Mo}_{7} \mathrm{O}_{24} \cdot 4 \mathrm{H}_{2} \mathrm{O}$ in a $\mathrm{Na}: \mathrm{Cr}: \mathrm{Mo}$ molar ratio of 1:1:4, respectively. The resulting mixture was calcined at $673 \mathrm{~K}$ to remove volatiles including $\mathrm{NO}_{2}, \mathrm{NH}_{3}$ and $\mathrm{H}_{2} \mathrm{O}$. The residual powder thus obtained was finely ground

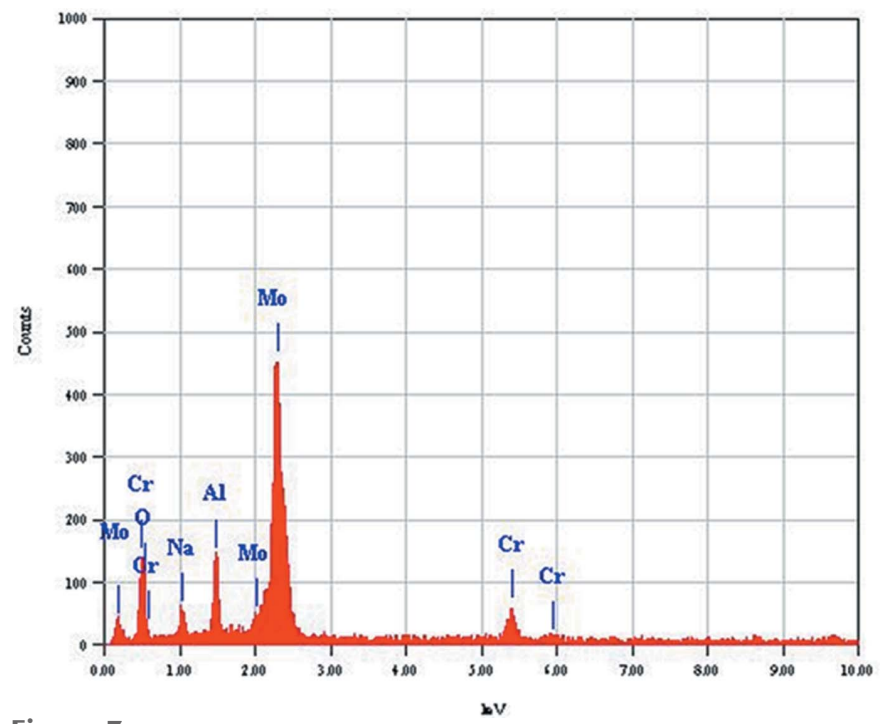

Figure 7

EDX analysis of the sample confirming the presence of aluminium in $\mathrm{Na}_{0.72}\left(\mathrm{Cr}_{0.48}, \mathrm{Al}_{1.52}\right)\left(\mathrm{Mo}_{2.77}, \mathrm{Al}_{0.23}\right) \mathrm{O}_{12}$. 
Table 3

Experimental details.

\begin{tabular}{|c|c|}
\hline \multicolumn{2}{|l|}{ Crystal data } \\
\hline Chemical formula & $\begin{array}{l}\mathrm{Na}_{0.72}\left(\mathrm{Cr}_{0.48} \cdot \mathrm{Al}_{1.52}\right)- \\
\quad\left(\mathrm{Mo}_{2.77} \cdot \mathrm{Al}_{0.23}\right) \mathrm{O}_{12}\end{array}$ \\
\hline$M_{\mathrm{r}}$ & 546.34 \\
\hline Crystal system, space group & Trigonal, $R \overline{3} c$ \\
\hline Temperature $(\mathrm{K})$ & 298 \\
\hline$a, c(\AA)$ & $9.217(2), 22.646(2)$ \\
\hline$V\left(\AA^{3}\right)$ & $1666.1(7)$ \\
\hline$Z$ & 6 \\
\hline Radiation type & Mo $K \alpha$ \\
\hline$\mu\left(\mathrm{mm}^{-1}\right)$ & 3.74 \\
\hline Crystal size (mm) & $0.24 \times 0.21 \times 0.18$ \\
\hline \multicolumn{2}{|l|}{ Data collection } \\
\hline Diffractometer & Enraf-Nonius CAD-4 \\
\hline Absorption correction & $\psi$ scan (North et al., 1968$)$ \\
\hline$T_{\min }, T_{\max }$ & $0.491,0.599$ \\
\hline $\begin{array}{l}\text { No. of measured, independent and } \\
\text { observed }[I>2 \sigma(I)] \text { reflections }\end{array}$ & $2878,414,401$ \\
\hline$R_{\text {int }}$ & 0.026 \\
\hline$(\sin \theta / \lambda)_{\max }\left(\AA^{-1}\right)$ & 0.637 \\
\hline \multicolumn{2}{|l|}{ Refinement } \\
\hline$R\left[F^{2}>2 \sigma\left(F^{2}\right)\right], w R\left(F^{2}\right), S$ & $0.013,0.024,1.25$ \\
\hline No. of reflections & 414 \\
\hline No. of parameters & 35 \\
\hline No. of restraints & 2 \\
\hline$\Delta \rho_{\max }, \Delta \rho_{\min }\left(\mathrm{e} \AA^{-3}\right)$ & $0.23,-0.43$ \\
\hline
\end{tabular}

Computer programs: CAD-4 EXPRESS (Duisenberg, 1992; Macíček \& Yordanov, 1992), XCAD4 (Harms \& Wocadlo, 1995), SHELXS97 (Sheldrick, 2008), SHELXL2014 (Sheldrick, 2015), DIAMOND (Brandenburg, 2006), WinGX (Farrugia, 2012) and publCIF (Westrip, 2010).

and then returned to the oven at a temperature close to the melting point at $973 \mathrm{~K}$ for three days to promote germination and crystal growth. After cooling, crystals of parallelepipedal shape and optimal size for data collection were obtained. A crystal of a good quality, selected under a polarizing microscope, was used for intensity measurements

\section{Refinement}

Crystal data, data collection and structure refinement details are summarized in Table 3. After processing the data, the structure was solved successfully in the $R \overline{3} c$ space group, using direct methods implemented in the SHELXS97 program (Sheldrick, 2008). The molybdenum, chromium and oxygen atoms were located first. At this stage, an empirical $\psi$-scan correction (North et al., 1968) was applied. Difference-Fourier syntheses using the program SHELXL97 (Sheldrick, 2008), allowed the rest of the atoms in the cell to be localized. We obtained intense peaks close to $\mathrm{Cr}$ and $\mathrm{Mo}$; the liberation of the occupancy factors led to values different from the full site occupancy (0.62530 for Mo and 0.24035 for Cr). The EDX analysis (Fig. 7) of the sample confirmed the presence of aluminium and we then used EADP and EXYZ constraints as well as SUMP to refine Al1 with the Mo1 site and Al2 with the Cr1 site. After refinement and verification of the electrical neutrality, the final formula was $\mathrm{Na}_{0.72(1)}\left(\mathrm{Cr}_{0.48(1)}, \mathrm{Al}_{1.52(2)}\right)$ $\left(\mathrm{Mo}_{2.77(3)}, \mathrm{Al}_{0.23(2)}\right) \mathrm{O}_{12}$. The remaining maximum and minimum electron densities in the difference-Fourier map are acceptable and are at $0.78 \AA$ from the Mo1 site and at $0.89 \AA$ from the Mo2, respectively.

\section{Acknowledgements}

The authors wish to thank the Ministry of Higher Education and Scientific Research of Tunisia for the funding of the laboratory LMCTA LR15ES01.

\section{References}

Adams, S. (2003). softBV. University of Göttingen, Germany.

Brandenburg, K. (2006). DIAMOND. Crystal Impact GbR, Bonn, Germany.

Brown, I. D. (2002). The Chemical Bond in Inorganic Chemistry - The Bond Valence Model. Oxford University Press.

Brown, I. D. \& Altermatt, D. (1985). Acta Cryst. B41, 244-247.

Catti, M., Comotti, A., Di Blas, S. \& Ibberson, R. M. (2004). J. Mater. Chem. 14, 835-839.

Chakir, M., Jazouli, A. E. \& de Waal, D. (2003). Mater. Res. Bull. 38, 1773-1779.

Coquerel, G., Gicquel-Mayer, C., Mayer, M. \& Perez, G. (1983). Acta Cryst. C39, 1602-1604.

Duisenberg, A. J. M. (1992). J. Appl. Cryst. 25, 92-96.

Farrugia, L. J. (2012). J. Appl. Cryst. 45, 849-854.

Harms, K. \& Wocadlo, S. (1995). XCAD4. University of Marburg, Germany.

Harrison, W. T. A. \& Phillips, M. L. F. (2001). Acta Cryst. C57, 2-3.

Hoppe, R., Voigt, S., Glaum, H., Kissel, J., Müller, H. P. \& Bernet, K. (1989). J. Less-Common Met. 156, 105-122.

Kozhevnikova, N. M. \& Imekhenova, A. V. (2006). Zh. Neorg. Khim. 51, 4, 589-592.

Macíček, J. \& Yordanov, A. (1992). J. Appl. Cryst. 25, 73-80.

Nespolo, M. (2001). CHARDI-IT. Laboratoire CRM ${ }^{2}$, Université de Lorraine, Nancy, France.

Nespolo, M., Ferraris, G., Ivaldi, G. \& Hoppe, R. (2001). Acta Cryst. B57, 652-664.

North, A. C. T., Phillips, D. C. \& Mathews, F. S. (1968). Acta Cryst. A24, 351-359.

Prabaharan, S. R. S., Fauzi, A., Michael, M. S. \& Begam, K. M. (2004). Solid State Ionics, 171, 157-165.

Sheldrick, G. M. (2008). Acta Cryst. A64, 112-122.

Sheldrick, G. M. (2015). Acta Cryst. C71, 3-8.

Slater, P. R. \& Greaves, C. (1994). J. Mater. Chem. 4, 1463-1467.

Sun, Q., Ren, Q. Q. \& Fu, Z. W. (2012). Electrochem. Commun. 23, 145-148.

Tkachev, V. V., Ponomarev, V. I. \& Atovmyan, L. O. (1984). Zh. Strukt. Khim. 25, 128-134.

Westrip, S. P. (2010). J. Appl. Cryst. 43, 920-925. 


\section{supporting information}

Acta Cryst. (2018). E74, 406-409 [https://doi.org/10.1107/S2056989018003031]

Elaboration, structural study and validation of a new NASICON-type structure, $\mathrm{Na}_{0.72}\left(\mathrm{Cr}_{0.48}, \mathrm{Al}_{1.52}\right)\left(\mathrm{Mo}_{2.77}, \mathrm{Al}_{0.23}\right) \mathrm{O}_{12}$

\section{Manel Sonni, Imen Jendoubi and Mohamed Faouzi Zid}

Computing details

Data collection: CAD-4 EXPRESS (Duisenberg, 1992; Macíček \& Yordanov, 1992); cell refinement: CAD-4 EXPRESS

(Duisenberg, 1992; Macíček \& Yordanov, 1992); data reduction: XCAD4 (Harms \& Wocadlo, 1995); program(s) used to solve structure: SHELXS97 (Sheldrick, 2008); program(s) used to refine structure: SHELXL2014 (Sheldrick, 2015); molecular graphics: DIAMOND (Brandenburg, 2006); software used to prepare material for publication: WinGX (Farrugia, 2012) and publCIF (Westrip, 2010).

Sodium chromium/aluminium molybdenum/aluminium dodecaoxide

Crystal data

$\mathrm{Na}_{0.72}\left(\mathrm{Cr}_{0.48} \cdot \mathrm{Al}_{1.52}\right)\left(\mathrm{Mo}_{2.77} \cdot \mathrm{Al}_{0.23}\right) \mathrm{O}_{12}$

$D_{\mathrm{x}}=3.267 \mathrm{Mg} \mathrm{m}^{-3}$

$M_{r}=546.34$

Trigonal, $R \overline{3} c$

$a=9.217(2) \AA$

$c=22.646(2) \AA$

$V=1666.1(7) \AA^{3}$

Mo $K \alpha$ radiation, $\lambda=0.71073 \AA$

Cell parameters from 25 reflections

$\theta=12.1-14.8^{\circ}$

$Z=6$

$\mu=3.74 \mathrm{~mm}^{-1}$

$T=298 \mathrm{~K}$

$F(000)=1526$

Prism, red

$0.24 \times 0.21 \times 0.18 \mathrm{~mm}$

Data collection

Enraf-Nonius CAD-4

diffractometer

Radiation source: fine-focus sealed tube

$\omega / 2 \theta$ scans

Absorption correction: $\psi$ scan

(North et al., 1968)

$T_{\min }=0.491, T_{\max }=0.599$

2878 measured reflections

414 independent reflections

Refinement

Refinement on $F^{2}$

Least-squares matrix: full

$R\left[F^{2}>2 \sigma\left(F^{2}\right)\right]=0.013$

$w R\left(F^{2}\right)=0.024$

$S=1.25$

414 reflections

35 parameters

2 restraints
401 reflections with $I>2 \sigma(I)$

$R_{\text {int }}=0.026$

$\theta_{\text {max }}=26.9^{\circ}, \theta_{\min }=3.1^{\circ}$

$h=-11 \rightarrow 11$

$k=-2 \rightarrow 11$

$l=-28 \rightarrow 28$

2 standard reflections every 120 reflections intensity decay: $0.8 \%$

$$
\begin{aligned}
& w=1 /\left[\sigma^{2}\left(F_{\mathrm{o}}^{2}\right)+4.1215 P\right] \\
& \text { where } P=\left(F_{\mathrm{o}}^{2}+2 F_{\mathrm{c}}^{2}\right) / 3 \\
& (\Delta / \sigma)_{\max }=0.001 \\
& \Delta \rho_{\max }=0.23 \mathrm{e} \AA^{-3} \\
& \Delta \rho_{\min }=-0.42 \mathrm{e} \AA^{-3}
\end{aligned}
$$

Extinction correction: SHELXL2014 (Sheldrick, 2015),

$\mathrm{Fc}^{*}=\mathrm{kFc}\left[1+0.001 \times \mathrm{Fc}^{2} \lambda^{3} / \sin (2 \theta)\right]^{-1 / 4}$

Extinction coefficient: 0.00046 (6) 


\section{Special details}

Geometry. All esds (except the esd in the dihedral angle between two 1.s. planes) are estimated using the full covariance matrix. The cell esds are taken into account individually in the estimation of esds in distances, angles and torsion angles; correlations between esds in cell parameters are only used when they are defined by crystal symmetry. An approximate (isotropic) treatment of cell esds is used for estimating esds involving l.s. planes.

Refinement. Refinement of $\mathrm{F}^{2}$ against ALL reflections. The weighted R-factor $\mathrm{wR}$ and goodness of fit $\mathrm{S}$ are based on $\mathrm{F}^{2}$, conventional $R$-factors $R$ are based on $F$, with $F$ set to zero for negative $F^{2}$. The threshold expression of $F^{2}>2 \operatorname{sigma}\left(\mathrm{F}^{2}\right)$ is used only for calculating R-factors(gt) etc. and is not relevant to the choice of reflections for refinement. R-factors based on $\mathrm{F}^{2}$ are statistically about twice as large as those based on F, and R- factors based on ALL data will be even larger.

Fractional atomic coordinates and isotropic or equivalent isotropic displacement parameters $\left(\AA^{2}\right)$

\begin{tabular}{llllll}
\hline & $x$ & $y$ & $z$ & $U_{\text {iso }} * / U_{\mathrm{eq}}$ & Occ. $(<1)$ \\
\hline Mo1 & $0.28488(2)$ & 0.0000 & 0.7500 & $0.01214(9)$ & $0.921(6)$ \\
A11 & $0.28488(2)$ & 0.0000 & 0.7500 & $0.01214(9)$ & $0.080(10)$ \\
Cr1 & 0.0000 & 0.0000 & $0.63854(3)$ & $0.0109(2)$ & $0.238(11)$ \\
A12 & 0.0000 & 0.0000 & $0.63854(3)$ & $0.0109(2)$ & $0.761(19)$ \\
Na1 & 0.0000 & 0.0000 & 0.5000 & $0.0259(9)$ & $0.724(8)$ \\
O1 & $0.48491(19)$ & $0.17851(19)$ & $0.74736(7)$ & $0.0326(4)$ & \\
O2 & $0.1686(2)$ & $-0.0152(2)$ & $0.68761(6)$ & $0.0376(5)$ & \\
\hline
\end{tabular}

Atomic displacement parameters $\left(\AA^{2}\right)$

\begin{tabular}{lllllll}
\hline & $U^{11}$ & $U^{22}$ & $U^{33}$ & $U^{12}$ & $U^{13}$ & $U^{23}$ \\
\hline Mo1 & $0.01265(11)$ & $0.01229(13)$ & $0.01137(12)$ & $0.00614(6)$ & $0.00085(4)$ & $0.00169(8)$ \\
A11 & $0.01265(11)$ & $0.01229(13)$ & $0.01137(12)$ & $0.00614(6)$ & $0.00085(4)$ & $0.00169(8)$ \\
Cr1 & $0.0117(3)$ & $0.0117(3)$ & $0.0092(3)$ & $0.00587(14)$ & 0.000 & 0.000 \\
A12 & $0.0117(3)$ & $0.0117(3)$ & $0.0092(3)$ & $0.00587(14)$ & 0.000 & 0.000 \\
Na1 & $0.0322(11)$ & $0.0322(11)$ & $0.0132(12)$ & $0.0161(6)$ & 0.000 & 0.000 \\
O1 & $0.0254(8)$ & $0.0218(8)$ & $0.0442(9)$ & $0.0071(7)$ & $-0.0038(6)$ & $0.0003(7)$ \\
O2 & $0.0364(9)$ & $0.0446(11)$ & $0.0278(8)$ & $0.0172(8)$ & $-0.0093(7)$ & $0.0015(7)$ \\
\hline
\end{tabular}

Geometric parameters $\left(\AA,{ }^{o}\right)$

\begin{tabular}{|c|c|c|c|}
\hline $\mathrm{Mo} 1-\mathrm{O} 2^{\mathrm{i}}$ & $1.7358(15)$ & $\mathrm{Na} 1-\mathrm{O} 1^{\mathrm{ii}}$ & $2.4987(15)$ \\
\hline $\mathrm{Mo} 1-\mathrm{O} 2$ & $1.7359(15)$ & $\mathrm{Na} 1-\mathrm{O} 1^{\text {vii }}$ & $2.4987(15)$ \\
\hline Mo1-O1 & $1.7540(16)$ & $\mathrm{Na} 1-\mathrm{O} 1^{\mathrm{iii}}$ & $2.4987(15)$ \\
\hline $\mathrm{Mo1}-\mathrm{O} 1^{\mathrm{i}}$ & $1.7540(15)$ & $\mathrm{Na} 1-\mathrm{O} 1^{\text {viii }}$ & $2.4987(15)$ \\
\hline $\mathrm{Cr} 1-\mathrm{O} 1^{\mathrm{ii}}$ & $1.9668(16)$ & $\mathrm{Na} 1-\mathrm{O}^{\text {iv }}$ & $2.4987(15)$ \\
\hline $\mathrm{Cr} 1-\mathrm{O} 1^{\mathrm{iii}}$ & $1.9668(16)$ & $\mathrm{Na} 1-\mathrm{O} 1^{\mathrm{ix}}$ & $2.4987(15)$ \\
\hline $\mathrm{Cr} 1-\mathrm{O}^{\mathrm{iv}}$ & $1.9669(16)$ & $\mathrm{Na} 1-\mathrm{Al}^{\mathrm{x}}$ & $3.1373(7)$ \\
\hline $\mathrm{Cr} 1-\mathrm{O} 2$ & $1.9720(16)$ & $\mathrm{Na} 1-\mathrm{Cr}^{\mathrm{x}}$ & $3.1373(7)$ \\
\hline $\mathrm{Cr} 1-\mathrm{O} 2^{\mathrm{v}}$ & $1.9721(16)$ & $\mathrm{O} 1-\mathrm{A} 12^{\mathrm{iii}}$ & $1.9668(16)$ \\
\hline $\mathrm{Cr} 1-\mathrm{O} 2^{\mathrm{vi}}$ & $1.9721(16)$ & $\mathrm{O} 1-\mathrm{Cr} 1^{\mathrm{iii}}$ & $1.9668(16)$ \\
\hline $\mathrm{Cr} 1-\mathrm{Na} 1$ & $3.1374(7)$ & $\mathrm{O} 1-\mathrm{Na} 1^{\mathrm{xi}}$ & $2.4987(15)$ \\
\hline $\mathrm{O} 2 \mathrm{i}-\mathrm{Mo} 1-\mathrm{O} 2$ & $109.56(11)$ & $\mathrm{O} 1^{\mathrm{iii}}-\mathrm{Na} 1-\mathrm{O} 1^{\mathrm{iv}}$ & $65.74(6)$ \\
\hline $\mathrm{O} 2^{\mathrm{i}}-\mathrm{Mo} 1-\mathrm{O} 1$ & $107.85(8)$ & $\mathrm{O} 1^{\mathrm{viii}}-\mathrm{Na} 1-\mathrm{O} 1^{\mathrm{iv}}$ & $114.26(6)$ \\
\hline $\mathrm{O} 2-\mathrm{Mo} 1-\mathrm{O} 1$ & $111.40(8)$ & 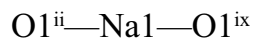 & $114.26(6)$ \\
\hline
\end{tabular}




\begin{tabular}{|c|c|c|c|}
\hline $\mathrm{O} 2^{\mathrm{i}}-\mathrm{Mo1}-\mathrm{O} 1^{\mathrm{i}}$ & $111.40(8)$ & 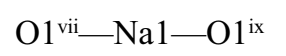 & $65.74(6)$ \\
\hline $\mathrm{O} 2-\mathrm{Mo} 1-\mathrm{O} 1^{\mathrm{i}}$ & $107.86(8)$ & 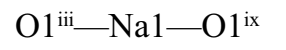 & $114.26(6)$ \\
\hline $\mathrm{O} 1-\mathrm{Mo} 1-\mathrm{O}^{\mathrm{i}}$ & $108.80(11)$ & $\mathrm{O} 1^{\text {viii_- }} \mathrm{Na} 1-\mathrm{O} 1^{\mathrm{ix}}$ & $65.74(6)$ \\
\hline $\mathrm{O} 1^{\mathrm{ii}-} \mathrm{Cr} 1-\mathrm{O} 1^{\mathrm{iii}}$ & $87.18(7)$ & $\mathrm{O} 1^{\mathrm{iv}}-\mathrm{Na} 1-\mathrm{O} 1^{\text {ix }}$ & 180.0 \\
\hline $\mathrm{O} 1^{\mathrm{ii}-} \mathrm{Cr} 1-\mathrm{O} 1^{\mathrm{iv}}$ & $87.18(7)$ & $\mathrm{O} 1^{\mathrm{ii}}-\mathrm{Na} 1-\mathrm{A} 12^{\mathrm{x}}$ & $141.20(4)$ \\
\hline $\mathrm{O} 1^{\mathrm{iii}}-\mathrm{Cr} 1-\mathrm{O} 1^{\mathrm{iv}}$ & $87.18(7)$ & 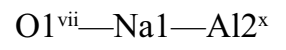 & $38.80(4)$ \\
\hline $\mathrm{O} 1^{\mathrm{ii}}-\mathrm{Cr} 1-\mathrm{O} 2$ & $92.79(7)$ & 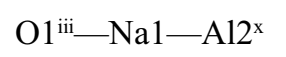 & $141.19(4)$ \\
\hline $\mathrm{O} 11^{\mathrm{ii}}-\mathrm{Cr} 1-\mathrm{O} 2$ & $88.68(7)$ & $\mathrm{O} 1^{\text {viii }-\mathrm{Na} 1-\mathrm{A} 12^{\mathrm{x}}}$ & $38.81(4)$ \\
\hline $\mathrm{O} 11^{\mathrm{iv}}-\mathrm{Cr} 1-\mathrm{O} 2$ & $175.86(7)$ & $\mathrm{O} 1^{\mathrm{iv}}-\mathrm{Na} 1-\mathrm{A} 12^{\mathrm{x}}$ & $141.19(4)$ \\
\hline $\mathrm{O} 1^{\mathrm{ii}}-\mathrm{Cr} 1-\mathrm{O} 2^{\mathrm{v}}$ & $88.68(7)$ & $\mathrm{O} 1^{\mathrm{ix}}-\mathrm{Na} 1-\mathrm{A} 12^{\mathrm{x}}$ & $38.81(4)$ \\
\hline 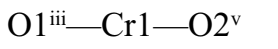 & $175.86(7)$ & $\mathrm{O} 1^{\mathrm{ii}}-\mathrm{Na} 1-\mathrm{Cr} 1^{\mathrm{x}}$ & $141.20(4)$ \\
\hline $\mathrm{O} 1^{\mathrm{iv}}-\mathrm{Cr} 1-\mathrm{O} 2^{\mathrm{v}}$ & $92.79(7)$ & $\mathrm{O} 1^{\mathrm{vii}}-\mathrm{Na} 1-\mathrm{Cr}^{\mathrm{x}}$ & $38.80(4)$ \\
\hline $\mathrm{O} 2-\mathrm{Cr} 1-\mathrm{O} 2^{\mathrm{v}}$ & $91.35(7)$ & $\mathrm{O} 1^{\mathrm{iii}}-\mathrm{Na} 1-\mathrm{Cr} 1^{\mathrm{x}}$ & $141.19(4)$ \\
\hline $\mathrm{O} 1^{\mathrm{ii}}-\mathrm{Cr} 1-\mathrm{O} 2^{\mathrm{vi}}$ & $175.85(7)$ & $\mathrm{O} 1^{\text {viii }-\mathrm{Na} 1-\mathrm{Cr}^{\mathrm{x}}}$ & $38.81(4)$ \\
\hline $\mathrm{O} 1^{\mathrm{iii}}-\mathrm{Cr} 1-\mathrm{O} 2^{\mathrm{vi}}$ & $92.79(7)$ & $\mathrm{O} 1^{\mathrm{iv}}-\mathrm{Na} 1-\mathrm{Cr} 1^{\mathrm{x}}$ & $141.19(4)$ \\
\hline $\mathrm{O} 1^{\mathrm{iv}}-\mathrm{Cr} 1-\mathrm{O} 2^{\mathrm{vi}}$ & $88.68(7)$ & $\mathrm{O} 1^{\mathrm{ix}}-\mathrm{Na} 1-\mathrm{Cr} 1^{\mathrm{x}}$ & $38.81(4)$ \\
\hline $\mathrm{O} 2-\mathrm{Cr} 1-\mathrm{O} 2^{\mathrm{vi}}$ & $91.35(7)$ & $\mathrm{A} 12^{\mathrm{x}}-\mathrm{Na} 1-\mathrm{Cr}^{\mathrm{x}}$ & 0.0 \\
\hline $\mathrm{O} 2^{\mathrm{v}}-\mathrm{Cr} 1-\mathrm{O} 2^{\mathrm{vi}}$ & $91.35(7)$ & $\mathrm{O} 1{ }^{\mathrm{ii}}-\mathrm{Na} 1-\mathrm{Cr} 1$ & $38.80(4)$ \\
\hline $\mathrm{O} 1^{\mathrm{ii}}-\mathrm{Cr} 1-\mathrm{Na} 1$ & $52.76(5)$ & 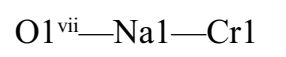 & $141.20(4)$ \\
\hline $\mathrm{O} 1{ }^{\mathrm{iii}}-\mathrm{Cr} 1-\mathrm{Na} 1$ & $52.76(5)$ & $\mathrm{O} 1{ }^{\mathrm{iii}}-\mathrm{Na} 1-\mathrm{Cr} 1$ & $38.81(4)$ \\
\hline $\mathrm{O} 1^{\mathrm{iv}}-\mathrm{Cr} 1-\mathrm{Na} 1$ & $52.76(5)$ & $\mathrm{O} 1^{\text {viii_-Na1-Cr1 }}$ & $141.19(4)$ \\
\hline $\mathrm{O} 2-\mathrm{Cr} 1-\mathrm{Na} 1$ & $124.30(5)$ & $\mathrm{O} 1^{\mathrm{iv}}-\mathrm{Na} 1-\mathrm{Cr} 1$ & $38.81(4)$ \\
\hline $\mathrm{O} 2$ - $-\mathrm{Cr} 1-\mathrm{Na} 1$ & $124.30(5)$ & $\mathrm{O} 1^{\mathrm{ix}}-\mathrm{Na} 1-\mathrm{Cr} 1$ & $141.19(4)$ \\
\hline $\mathrm{O} 2^{\mathrm{vi}}-\mathrm{Cr} 1-\mathrm{Na} 1$ & $124.30(5)$ & $\mathrm{A} 12^{\mathrm{x}}-\mathrm{Na} 1-\mathrm{Cr} 1$ & 180.0 \\
\hline $\mathrm{O} 1^{\mathrm{ii}}-\mathrm{Na} 1-\mathrm{O} 1^{\mathrm{vii}}$ & 180.0 & $\mathrm{Cr} 1{ }^{\mathrm{x}}-\mathrm{Na} 1-\mathrm{Cr} 1$ & 180.0 \\
\hline 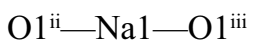 & $65.74(6)$ & $\mathrm{Mo} 1-\mathrm{O} 1-\mathrm{A} 12^{\mathrm{iii}}$ & $144.66(9)$ \\
\hline $\mathrm{O} 1^{\mathrm{vii}}-\mathrm{Na} 1-\mathrm{O} 1^{\mathrm{iii}}$ & $114.26(6)$ & $\mathrm{Mo} 1-\mathrm{O} 1-\mathrm{Cr} 1^{\mathrm{iii}}$ & $144.66(9)$ \\
\hline 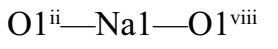 & $114.26(6)$ & $\mathrm{A} 12^{\mathrm{iii}}-\mathrm{O} 1-\mathrm{Cr} 1^{\mathrm{iii}}$ & 0.0 \\
\hline $\mathrm{O} 1^{\mathrm{vii}}-\mathrm{Na} 1-\mathrm{O} 1^{\text {viii }}$ & $65.74(6)$ & $\mathrm{Mo} 1-\mathrm{O} 1-\mathrm{Na} 1^{\mathrm{xi}}$ & $126.81(8)$ \\
\hline $\mathrm{O} 1^{\mathrm{iii}}-\mathrm{Na} 1-\mathrm{O} 1^{\mathrm{viii}}$ & 180.0 & 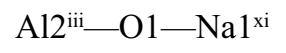 & $88.43(6)$ \\
\hline 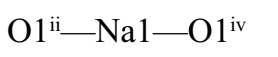 & $65.74(6)$ & $\mathrm{Cr} 1^{\mathrm{iii}}-\mathrm{O} 1-\mathrm{Na} 1^{\mathrm{xi}}$ & $88.43(6)$ \\
\hline 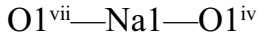 & $114.26(6)$ & $\mathrm{Mo} 1-\mathrm{O} 2-\mathrm{Cr} 1$ & $158.35(10)$ \\
\hline
\end{tabular}

Symmetry codes: (i) $x-y,-y,-z+3 / 2$; (ii) $x-y-1 / 3, x-2 / 3,-z+4 / 3$; (iii) $-x+2 / 3,-y+1 / 3,-z+4 / 3$; (iv) $y-1 / 3,-x+y+1 / 3,-z+4 / 3$; (v) $-x+y,-x, z$; (vi) $-y, x-y$, $z$; (vii) $-x+y+1 / 3,-x+2 / 3, z-1 / 3$; (viii) $x-2 / 3, y-1 / 3, z-1 / 3$; (ix) $-y+1 / 3, x-y-1 / 3, z-1 / 3$; (x) $-x,-y,-z+1$; (xi) $x+2 / 3, y+1 / 3, z+1 / 3$. 